$1-1-1900$

\title{
Report on examination of wheat stubble from different sections of the state ; The joint worm in wheat in the northern panhandle and northern borders of the state
}

\author{
A. D. Hopkins
}

Follow this and additional works at: https://researchrepository.wvu.edu/ wv_agricultural_and_forestry_experiment_station_bulletins

\section{Digital Commons Citation}

Hopkins, A. D., "Report on examination of wheat stubble from different sections of the state ; The joint worm in wheat in the northern panhandle and northern borders of the state" (1900). West Virginia Agricultural and Forestry Experiment Station Bulletins. 69.

https://researchrepository.wvu.edu/wv_agricultural_and_forestry_experiment_station_bulletins/69 @ WVU. It has been accepted for inclusion in West Virginia Agricultural and Forestry Experiment Station Bulletins by an authorized administrator of The Research Repository @ WVU. For more information, please contact ian.harmon@mail.wvu.edu. 
$-$

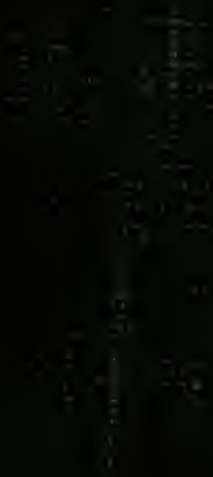


Digitized by the Internet Archive in 2010 with funding from

Lyrasis Members and Sloan Foundation 
WEST VIRGINIA UNIVERSITY

AGRICULTURAL EXPERIMENT STATION,

MORGANTOWN, W. VA.

Bulletin 69.

OCTOBER, 1900.

\section{REPORT ON EXAMINATION OF WHEAT}

\section{STUBBLE FROM DIFFERENT SEC-}

\section{TIONS OF THE STATE.}

SUPPLEMEN'T TO BULIETIN 67.

THE HESSIAN FLY IN WEST VIRGINIA.

\section{THE JOINT WORM IN WHEAT}

IN THE NORTHERN PANHANDLE AND NORTHERN BORDERS OF THE STATE.

BY A. D. HOPKINS, PH. D. 


\section{THE REGENTS OF THE WEST VIRGINIA UNIVERSITY.}

NAME OF REGENTS.

Hon. George C. Sturgiss

Hon. James F. Brown

Hon. A. H. Kunst

Hon. Richard Randolph McMahon

Hon. Johñ J. Davìs

Hon. James L. Hamill

Hon. John A. CampBell

Hon. W. E. Powell -

Hon P. C. EasthaM
P. O. ADDRESS.

Morgantown

Charleston

Weston

Harper's Ferry

Clarksburg

Welch

New Cumberland.

Parkersburg

Pt. Pleasant

\section{STATION COMMITTEE.}

George C. Sturgiss.

James L Hamill

James F. Brown.

President Regents

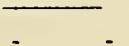

Geo. C. Sturgiss

President University - Jerome H. Raymond, A. M., Ph. D

Treasurer

A. R. Whitehill, Ph. D.

Auditor

S. G. ChADwICK

STATIUN STAFF.

James H. Strewart, A. H.,

A. D. Hopkins, Ph. D.,

Bert H Hite, M. S.,

L. C. Corbett, M. S.

W. E. Rumsey, B. S. Agr.

Horace Atwood, M. S

C. D. How a Rd, B. S.

E. C. Frame

M. A. Stewart
Director and Agriculturist

Vice Director and Entomologist

Chemist

- Horticulturist

Assistant Entomologist

-Assistant Agriculturist

Assistant Chemist

- Clerk and Stenographer

Librarian 
SUPPLEMENT TO BULLETIN No. 67.

\section{REPORT ON EXAMINATION OF WHEAT STUBBLE SENT IN BY CORRESPOND. ENTS FROM DIFFERENT COUNTIES.}

Between August 30th and October 1st, 45 samples of wheat stubble were received from 36 post offices and 24 counties. These bundles contained from 15 to 226 straws each, aggregating 3,208 straws, all of which were carefully examined by the writer with a view of obtaining information regarding the present condition of the flax seed stage of the fly in different sections of the state. The results show that out of the 3,208 straws examined, 1099 showed injury by the fly. The total number of the flaxseed stage (pupa) of the fly found under the leaf sheathes of the injured stems was 1,820 of which 1,659 were dead or empty and 877 had been killed by parasites. The remaining 782 dead examples, died from disease or other causes, or the fly had emerged. So far, only four living examples of the fly have emerged from the 161 pupa which appeared to be living when received. Many of the pupae thought to contain living larvae of the fly have since been found to contain parasite larrae, which had fed upon and killed the fly larvae.

\section{ENCOURAGING OUTLOOK.}

The most interesting feature of these results is the fact that practically all of the flaxseed stage of the fly found in the stubble from all the localities were dead and that more than half of them had been killed by parasites. Thus indicating that while the conditions may be slightly different in localities other than those from which stubble was received, and a few flies may survive in all sections, the prospect for little or no damage to wheat 
this fall or next spring is very encouraging. Therefore, if hereafter all wheat is sown late enough to escape the few surviving flies in the fall, and all volunteer wheat is destroyed, the pest should give much less trouble in the future.

The following table, giving the names of correspondents, post offices, counties, dates of sowing, etc., with results of examination, will show the comparative condition of samples of stubble from different sections. It will be noted that there are some apparent contradictions to the rule, but it must be remembered that our results relate to wheat damaged by the spring brood of the fly and that the late sown wheat may have been attacked in the spring only, from flies that breed in the early sown wheat. If, however, wheat sown as late or later than the dates given was attacked and injured in the fall in any locality, it was either due to retarded development of the fly due to drouth, or to local conditions. If the latter, a still later date should be selected. See Bulletin 67, page 245 . 


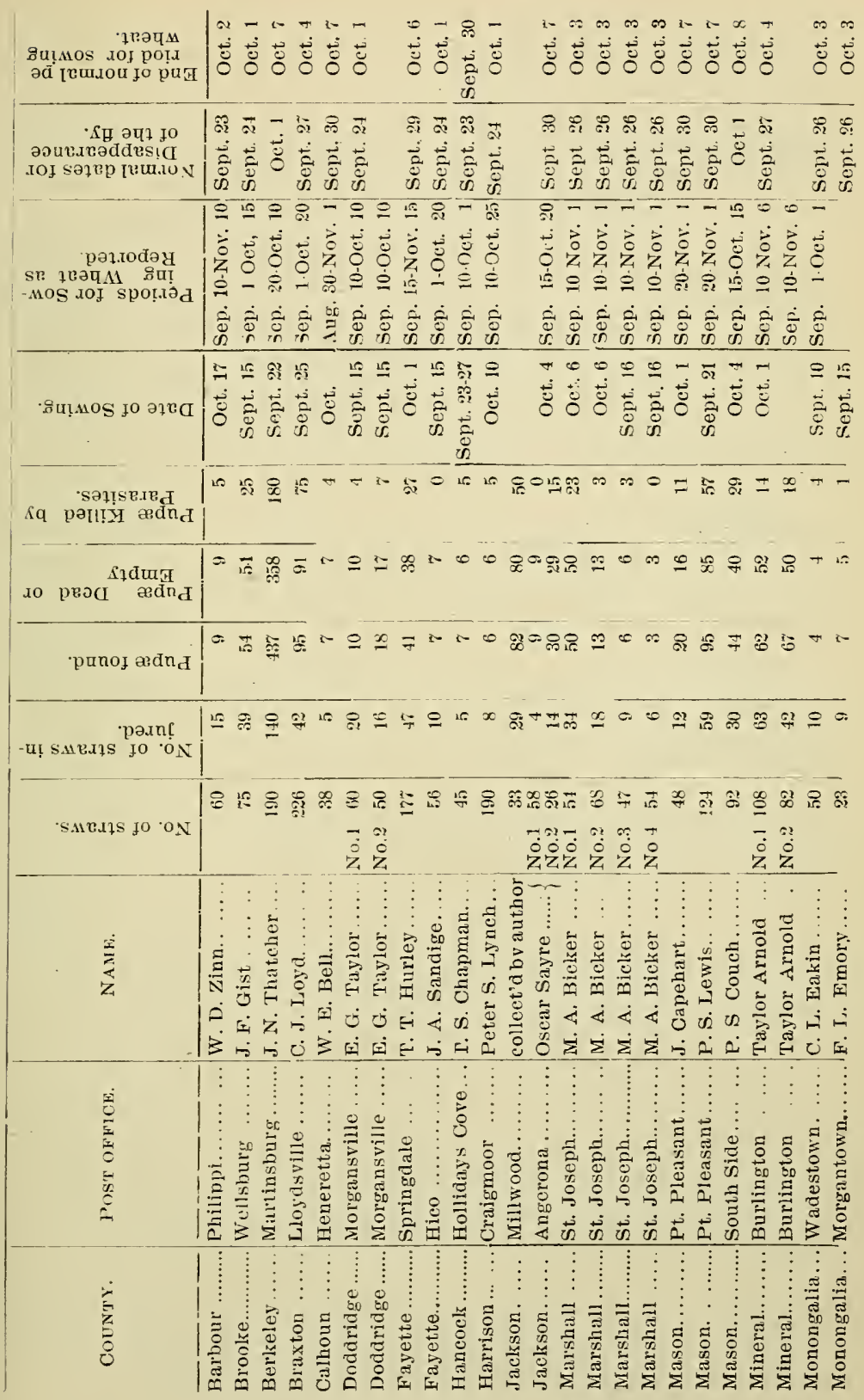




\begin{tabular}{|c|c|}
\hline 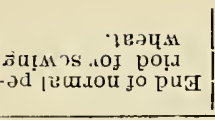 & 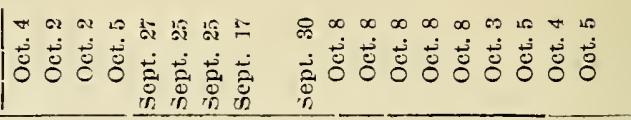 \\
\hline 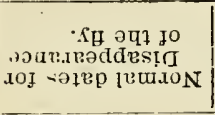 & 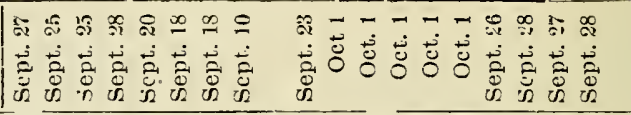 \\
\hline 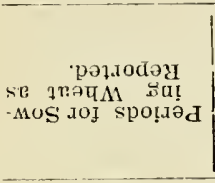 & 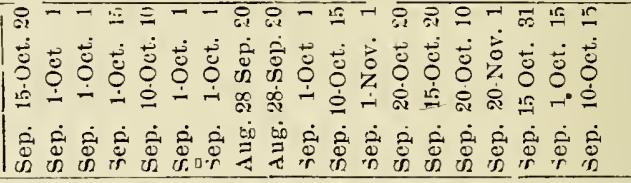 \\
\hline -8u!nos fo olen & 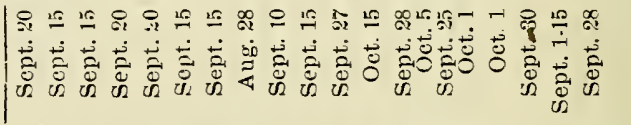 \\
\hline fq pəII!Y adis & T. \\
\hline $\begin{array}{c}\text { sidmig } \\
\text { to puod ædind }\end{array}$ & 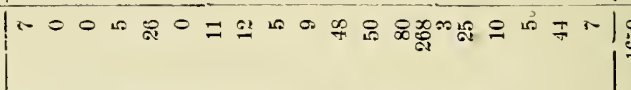 \\
\hline -punoj æđand & w00 - \\
\hline -ut SMBizs $\stackrel{\text { pəan! }}{\text { jo } 0_{\mathrm{N}}}$ & I \\
\hline 'SMr.l一 נо ${ }^{\circ} \mathrm{N}$ & 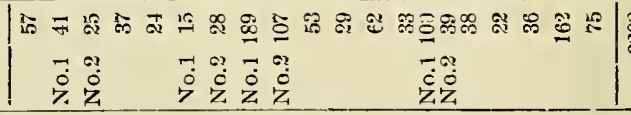 \\
\hline 运 & 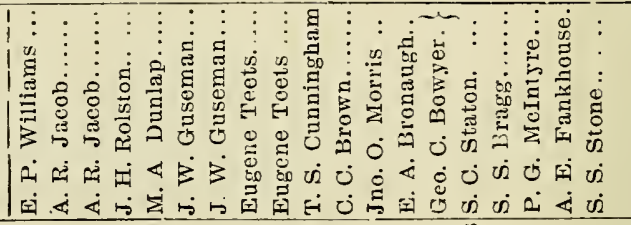 \\
\hline $\begin{array}{l}5 \\
0 \\
0 \\
0 \\
0 \\
0 \\
0 \\
0 \\
0\end{array}$ & 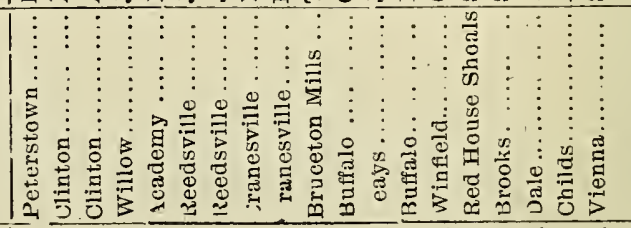 \\
\hline 岕 & 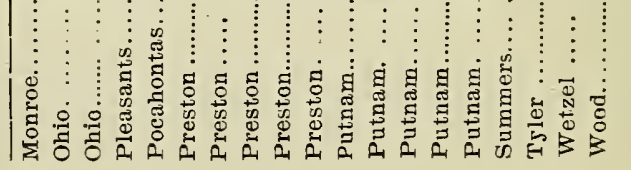 \\
\hline
\end{tabular}




\section{REPORTS OF CORRESPONDENTS WHO SENT WHEAT}

\section{STUBBLE FOR EXAMINATION.}

Barbour County:

Philippi-W. D. Zimu. Sept. 4 ; “'dark loam, bottom laud." Brooke County:

Wellsburg,一J. F. Gist, Sept., 4; "saudy loam, hill land. The field from which this stubble was taken was very badly damaged by the fly, not making more than three bushels to the acre." (The sample showed quite serious injury from the joint worm, and doubtless a large share of the damage blamed to the fly, was due to this insect.)

Braxton Counts:

Lloydsville-C. J. Lloyd, Sept., 14; “dark loam, hill land. The field from which this sample was taken was good except in patches, which had stiff purple straw, and was not filled."

Berkeley County:

Martinsburg-J. N. Thatcher, Sept., $15 ; "$ sand to soap stone, bottom land. The field from which this stubble was taken is orrued by O. H. Cushwa and was badly infested with Hessian fly. Part of the field was not worth cutting." (This sample showed by far the greatest number of the flax seed stage of any received. Nearly all were dead, however, and a large number had been killed by parasites. Some straws had as many as eleven "flaxseeds" crowded under the leaf sheath near one joint.)

Calhoun County:

Henrietta-W. E. Bell, Sept., 14: "light, red hill land. The stubble was taken from the sonth-west slope, of a flat on hill land; grain areraged six bushels per acre. Smallest I have raised for 12 years. The variety was Early Ripe. No fertilizer was used except a few loads of barn yard manure."

Doddridge County:

... Morgansville-E. G. Taylor, Sept. 4 ; "sandy clay, high bottom land. *** I do not know that the wheat from which I took the sample was injured by the fly, but at least three-fifths of it fell badly - just tangled in every direction; began to fall about the time wheat was in bloom ** I got the stubble from places where it was damaged worse."

Fay ette County:

Hico-J. A. Sandige, Sept. 4: "light clay hill land." spring Dale --T. T. Hurley, Sept 11: “dark saudy loam, hill land. The fly 
was very bad in this field and several others in this viciuity this year. It seems worse on the hill land and in fields sown early, especially where no fertilizer was used. Wheat was filled very well, but was so tangled that it could not be saved. This is the first year we have noticed the fly."

Hancock County :

Hollidays Cove-T. S. Chapman, Sept. 10; "light clay aud sandy loam, hill land. Our wheat looked well last fall, and I think it was injured more by the cold winter and the lack of fertilizer than by the Hessian fly. Our wheat was hardly worth cutting; only averaged five bushels to the acre. Will sow all my ground in rye this fall. I have an idea that the cause of our failure is the same as the failure in timothy and other grasses, namely some fungus or small insect working on the roots on the same priuciple as the scab works on the apples and fruit.", (The samples received from Mr. Chapman showed serious injury by the joint worm.)

Jacksou County :

Augerona-Oscar Sayre, Sept. 29; "white clay, hill land. Sample No. 1 was drilled and fertilizeri; No. 2 was plowed in with a shovel plow and harrowed, and was raised on new ground. It was the second crop and was sowu from the 6 th to 15 th of October. This land is dark loam, on north hill side."

Harrisou County:

Craigmoor-Peter I. Lynch, Sept. 8; "light clay, upland. I am not sure that the fly affected this wheat. It was rauk growth and was pastured off by ewes and lambs np to, I think, April 15 th; then later on we had frost in May, which caused it to tangle and fall. We threshed about 15 bushels per acre on the lot of 12 acres.",

Marshall County:

St Joseph--M. A. Bicker, Sept. 6; "clay Joam, hill or knob laud." (Considerable injury by the joint worm was found in this sample as well as by the stem maggot. Evidence was also found that the chinch bug had been preseut in cousiderable unmbers.)

Mason County :

Pt. Pleasaut-James Capehart, Sept. 7th, "clay, bottom laud. All wheat in this locality was hurt more or less by the fly, irrespective of the date of sowing. A drouth of six weeks in April and May gave the fly an unusual opportunity to multiply.', (The late sown wheat was evidently attack in the spring by the fly which bred in the early sown wheat. Observations on the habit of the fly indicates that wet weather is much more favorable to the fly to develope than dry weather, yet the drouth will so weaken the plant that a slight attack by the fly will show a greater effect than will a much worse atack on vigorous plants.)

Pt. Pleasant- P. S. Lewis, Sept. 4; "dark loam, Ohio river bottom 
land. It has been so long since harrest that weeds and grass have covered field and straw is nearly rotted. Field of sixty acres was in fine condition when drilled. The wheat came up and promised a good crop. The fly attack it and patches of oue half acre or more were very badly injured, showing plainly from railroad. The spring crop of flies [extended] over the whole field. The yield of grain was 15 bushels to the acre. If it had not been for the damage by the fly it would have been 25 bushels. Will not sow this fall nutil October." (A living chinch hug was found with the sample of straw, indicating the presence of this pest in that locality.)

South Side-Peter S. Couch, Sept.. 12; "red clay loam, bottom land. (Damage iess on dark sandy soil) * * * My wheat stubble was mown early in Angust and I could only find a small amount that the mower left standins." (Mowing stubble and leaving it on the ground will be of no advantage in destroying the fly; indeed, it will be a benefit to the flaxseed stags, which survives much better under moist conditions.)

Mouroe County:

Peterstown-E. P. Williams, Sept. 10; "light sandy, hill land. The sample of stubble is from a field I rented. The renter plowed the wheat in (abont September 20th) on corn stubble. The part of the field from which the stubble was gathered was badly cnt down by the fly. There is fifteen acres in the field and it made ouly about 85 bushels, or five aud a half bushels to the acre. I sowed a field near this one the first week in October, drilling the wheat (in corn land) after plowing the land well, using 200 pounds of good fertilizer per acre, and I got 339 bushels of good wheat off of abont 13 acres, or a yield of 26 bnshels per acre. This is good bottom land. * * * I take an interest in good farming and I intend to try every rear to increase the sield of grain per acre.",

Mineral County:

Burlingtou-Taylor Aruold, Sept. 12: "sample No. 1 on light gravel, hill laud: sample No. 2 clay, low land. * * * No. 1 gathered where the fly injured it so much that it was not worth cutting. No. 2 was cnt and ouly a little fly seemed ro be in it.", Monongalia Coutuy:

Wadestown-C. L. Eakin, Sept. 7 ; "dark bottom land. This field was almost destroyed by fly.',

Ohio County:

Clinton-A. R. Jacob, Sept. 5; "sandy loam, hill land. Bundle wrapped with red string, (No. 2 in table) taken from sandy soil which had been heavily manured, with stable aud sheep manure. (No.1 in table) grown on loamy soil, about all fallen flat down when harrested. The small pieces sent were taken out of 
granery. My observatiou is that they (the fly) appeared to attack wheat growu on limestome soils less than on other soils. 'This late in the season, with a heavy growth of clover and rag weed, it is quite difficult to find good specimeus." (Noue of these samples showed injury by the Hessian fly, except one straw in No. 1, but they were all very badly infested with the joirt worm. Thirteen pieces of the samples taken from the grauery, averaging one inch long, were found to contain 121 worms, all of which were dead, due, evidently, to the dry condition of the straw. The stubble taken from the field was found to be equally as badly infested and the worms were alive. A number of parasites of the joint worm were also present, but not in sufficieut numbers to be of any special value. It is evident therefore, that this is a very serions pest in that section of the state, and will require special effort on the part of farmers to prevent great loss in the future from its ravages. See recommendation on auother page.)

Pleasants County:

Willow-J. H. Rolston, Sept., 8; “dark clay, river botfom land. The grain began to fall about one week before it was ripe. I have threshed the crop and it averaged 15 bushels to the acre, should have made 20 ."

Pocahontas County:

Academy-M. A. Dunlap, Sept., 5; "clay and dark loam hill laud. This stubble is from a neighbor's field. My own wheat was sown about the same time on wheat stubble which was infested with fly. I plowed as soon as wheat was cut, and had no fly, while my neighbors all had. The spring brood is the one that does the damage here. The fall brood never. I once saw the fly destroyed in a field of wheat by being covered with sedement from river. * * * The river overflowed in the fall and covered the wheat to a depth, in some places, of eight inches. The wheat came through and made a fine crop. ** * The fly will not attack vigorous healthy wheat. Therefore early sown and well fertilized fields are immuue. Of course if we should ever be troubled by the fall brood it would be different. The strong vigorous stalks are not hurt in the spring even if attacked. If we have a wet, warm spring next year and no green aphis you will hear nothing of fly from this section. Last spring the aphis and the weather destroyed half the vitality of the plant and the fiy fiuished it. I will venture to say that no field in this state was hurt which had been topped dressed during the winter with stable mauure, or other nitrogenous manures. The trouble last spring was that * * * the wheat plant was not able to overcome the combined adverse conditions of which the aphidae were the worst. The fly got all the credit because he came last." 
Preston County:

Reedsville-J. W. Guseman, Sept., 4 ;"clay, hill land. The wheat crop was damaged bad in this county, and we are afraid to sow this fall."

Cranesville-Eugene Keets, Sept. 5; “No. 1, dark pine (spr'uce) old, bottom land: No. 2, new ground, chestuut hill land. Our wheat was right good in this section, considering the winter freeze and the Hessian fly. The fil was worse on some wheat than on others. My first sowing was the best and bothered the least by the fly. I drilled phosphate with wheat, and sprinkled manure on ground before drilling.' (One straw was found with sample No. 2, which was infested with the joint worm, and contained many living examples of this insect. The fact that wheat on bottom land, sown the last week in August was damaged less by the fly than that sown later, Sept. 10, on hill land, is very interesting, and indicates that in this locality, which is nearly 3,000 feet above sea level, there is probably but one brood of the fly, as is the case farther north where spring wheat is grown successfully. The normal date for the best period for sowing wheat in this locality, as indicated by latitude and altitnde, suggests that spring wheat might be more profitably grown that fall wheat, and we would suggest some experiments along that line.)

Bruceton Mills-P. S. Cunningham, Sept., 3; "clay or gravelly hill land. I think my wheat was hurt more by the frost in May and the drouth in June than it was by the Hessian fly, although the fly did his share. My fields only averaged 7 bushels per acre. The October sown wheat in this section did the best."

Putnam County:

Buffalo-C. C. Brown, Sept., 11; "light clay, second bottom. The stubble in the part of the field which was most affected is nearly all gone, but there was more or less fly in the part from which the stubble came. Part of the field was very good, but the average on the 27 acres was only about 12 bushel per acre. I will not sow this year until the first week in October, and in corn land, thoronghly prepared for the seed.

'Buffalo-E. A. Bronangh, Sept., 9; "light loam, bottom land. Stubble inclosed is of the best wheat, not at all, or but little damaged. Badly damaged stubble has been fallowed, or clipped to save grass. I fear that stubble inclosed will be of little benefit. I had abont seven acres of wheat stubble fallow that gave me about $\frac{1}{2}$ bushel of wheat per acre. My timothy land, with some clover, by the side of the stubble field gave me $\frac{1}{2}$ crop.",

Teays-Jno. O. Morris, Sept., 11; "clay loam, rolling land. The fly did not make its appearance in field from which sample was taken until April, but in an adjoining field, sown Sept. 15, it made its appearance as soon as the wheat came up last fall and 
killed most of it before it sent out branch roots and consequently it was not worth harresting. The wheat from field where sample was taken made $\tilde{b}$ bushels per acre. The usual yield from such land is from 15 to 20 bushels, when not troubled with the fly.", (Mrr. Moxris' observations are very interesting in the fact that they show how the fly, breeding in early sown wheat, may swarm in the spring and attack the late somn wheat which escaped injury in the fall.)

Red House-S. C. Staton, Sept.,6; "clay, Kanawha River bottom land."

Winfield-Geo. C. Boyers, Oct., 1; "Sample stubble from Jno. L. Strickland, light loam. creek bottom" and E. S. Cartmill, "dark loam, rirer bottom.'

Summers County:

Brooks-S. S. Bragg, Sept., 15; "dark clay, hill land. When I harrested $\mathrm{my}$ wheat I fornd several small flies or brown bugs in the stubble. My wheat did not make a half crop. It all fell down."

Tyler County:

Dale-E. G. McIntire, Sept., 1\%; "light clay, hill land. Part of the field was affected on light clay land.",

Wetzel County:

Childs-A. E. Frankhouser, Sept., 11: "dark sand, bottom land. Thinking of sowing later this fall."

Wood County:

Veinna - S. S. Stone, Sept., 10; "Iight sand on sand plain, land or so called mellon or garden land. The stubble inclosed is from the field of J. H. Spencer, being the worst field in the neightorhood. I examined this field in the fall and early winter. and conld find stalks with three or four insects in a single one. This field was not harrested, being entirely worthless."

REPORTS FROM CORRESPONDENTS WHO DID NOT SEND SAM-

\section{PLE OF STUBBLE.}

\section{Berkeley County:}

Martinsburg-Sept., G. W. Vanmeter, "I have dilligently inquired in regard to wheat affected by the fls, but no one seems to know where any was located. Parties who said they had the fly in the growing season, now say they do not know it was the fly.",

\section{Boone County:}

Hewett-W. E. Dent, Sept., 24; "Can not find aur wheat damaged by the Hessian Fly in this locality."

Brooke County:

Wellsburg-C. P. Waugh, Sept., 16; "The farmers in this part of the county had mown the wheat stubble before rour inquiry came. 
I am sorry for I am interested in this little pest, and it means a great deal to the farmers whether they have it or not.",

Calhoun County:

Arnoldsburg-E. W. Hall, Sept.,3; "I have made some inquiry regarding the Hessian Fly in this locality, and so far as I have been able to learn there has been no damage done to the wheat crop by it."

Hards County:

Old Fields-Ed W. McNeill. "We had no Hessian Fly this year, though the chinch bugs are arvful on the corn."

Jefferson County:

Kernessville--D. W. Border, Sept., 4; "Have canvassed my locality and can find no farmer who was troubled this season with the Hessian fly."

Jackson County:

Fair Plain-S. W. Harpold, Sept., 2; "My wheat was damaged very much by the fly, but the field was low bottom land, which was flooded in JulJ, and covered the stubble. so I cannot send you samples."

Lewis County:

Roanoke-M. M. Hevener, Sept., 5; "I do not know of any wheat in this neighborhood that was damaged by the fly the past rear, or at least not to any extent."

McDowell County:

Welsh-Henry C. Flesher, Sept., 3; "Little or no wheat is raised in McDowell county; therefore I cannot send you the stubble."

Pendleton County:

Uppertract-W. H. Cunningham, Sept., 24; "I have made inquiry but cannot hear of any trouble in this locality from the Hessian Fly. One man told me he found some in patches of his wheat, but could not get me any of the stubble now. The chinch bng has given me more trouble than any thing else this year. Mr wheat and corn fields are literally covered with them now."

Franklin-J. A. Dickinson, Oct., 1; "I was unable to get any stubble for you as there was no Fly in our locality last harvest. Two years ago there was a great deal of complaint,",

Randolph County:

Helretia-Christain Pauli, Sept., .ॅ;"The Hessian Fly has not done anj damage in onr locailty.'

Tucker County:

Texas--Elihn Philips, Sept., 3; "Wheat was not bothered in this section by the fly this jear to my knowledge."

Webster County:

Welsh Glade-J. E. Woods, Sept., 13; "There is very little wheat raised in this community, and I heard of no complaint of the fly.' 
Wirt County:

Newark-E. B. Hoff, Sept. 3; "The fly is not in this neighborhood that I know of."

Wyoming County

Oceana-C. F. Stewart, Sept., "We have but little wheat raised in this county, and I am informed that it was good."

\section{NOTE.}

Reports received since the above was sent to the press indicate that the fall drougth and long continued warm weather extending into November, enabled the fly to continue its flight much later than in normal seasons, and that in consequence late sown wheat has been damaged in some localities.

This should not, however, prevent farmers from giving the matter of late, and proper normal dates of sowing wheat due consideration in the future, for under normal conditions there is no doubt it will prevent a large amount of loss which would otherwise follow, 


\section{THE JOINT WORM.}

CAUSING SERIOUS DAMAGES TO WHEAT IN SOYE LOCALITIES.

The stubble received from Hancock, Brooke, Ohio, Wetzel, Monongalia and Preston counties showed injury from the joint worm, and the abundance of this pest, especially in the samples received from Mr. Jacob, Clinton, Ohio county, indicates that the old time destructive ravages by this pest are in danger of being repeated. The serious character of the damage and loss that this little insect is capable of inflicting and the rapidity with which it can multiply and spread renders it even worse than the Hessian fly. Therefore, every precaution should be taken by farmers in the infested area to suppress it and prevent future trouble.

The character of the injury by the Joint Worm is quite different from that caused by the fly, and may be readily recognized from the following description: The straws of wheat infested by the joint worm have the joints and the portions of the straw between the joints abnomally enlarged, distorted (Plate 1-c) and the infested portions solid and woody, and upon cutting into the enlarged and roody portions numerous cavities are found, (d) each of which, at any time between wheat harvest and the first of the following May will usually contain a slender yellow worm or larvae (the true joint worm.) The larva changes first to an inactive stage, the pupa, then to a minute four winged gnat, (Plate 1-a) and ernerges from the stem during the month of May, the time varying with the latitude and altitude. The females then deposit their eggs in the stems of the growing wheat and the young "worms" hatching therefrom cause the thickened, hardened stems, and prevent a normal development of the grain. When the wheat, barley or rye that is infested by the joint worm is threshed, a large quantity of short pieces of straw will come out with the grain (Plate 1-e). Upon examina- 
tion these will be found to be solid and heavy and infested with a great number of the insect.

HETHODS OF COHBATTING THIS PEST.

The joint worm passes the summer, fall and winter in the stubble and straw and emerges in May. With this knowledge of the habits of the insect it is plain that if all wheat, barley, and rye stubble and straw could be composted or burned before the first of May the insect could not survive. While it may not ba possible to accomplish this in as thorough a manner as would be necessary to exterminate the pest, it can doubtless be practiced to a sufficient extent to reduce the numbers of the insect beyond its power of causing perceptible loss of grain.

We would recommend the following as perhaps the most practicable and best methods of preventing loss from the ravages of the joint worm :

First: When harvesting the grain cut as high as practicable.

Second: As soon after harvest as convenient, or before the stubble is beaten down by rains or tramped down by stock, run a mowing machine over the field with the cutter bar as low as possible; then rake up the stubble with a sulky rake. If stacked or stored in the barn it may be used as bedding for stock during the winter. It is especially important that all of the stubble, as well as the straw saved for the purpose should be used in this manner and thoroughly composted or spread and plowed under before the first of May. If it is not practicable or desirable to follow this method, the next best thing is to burn all badly infested stubble and straw, or plow it under deeply and thoroughly. It is quite important, however, that one or all of these methods be generally adopted in each locality in order to obtain the best results.

It is probable that some varieties of wheat, furnish in the character of the straw, much more favorable conditions for attack by the insect than others varieties, and this is a subject to be kept in mind and results noted by wheat growers.

We hope to give considerable attention to this insect during 
the winter and next spring, and will be greatly aided in obtaining the best results if farmers will send us samples of infested straw with information relating to the variety of wheat, char. acter of soil, extant of damage and any other information relating to practical experience and observation. 


\section{THE JOINT WORM. \\ Explanation of Plate 1.}

a. Adult female of Joint Worm--greatly enlarged.

b. Adult female and male parasite of Joint Worm-greatly eularged.

c. Wheat straws showing characteristic appearance, when infested with Joint Worm.

d. Pieces of straws with onter portion cut away to show cavities in which the worms live.

e. Pieces of straw that came through the machine with the grain when threshing.

f. Infested straw bent over. The small round holes seen in c. e. and $f$. are those made by the adult parasites when emerging from the straw. 
Supplement to Bulletin 6r, W. Va. Agr. Expt. Station.

PLATE I.

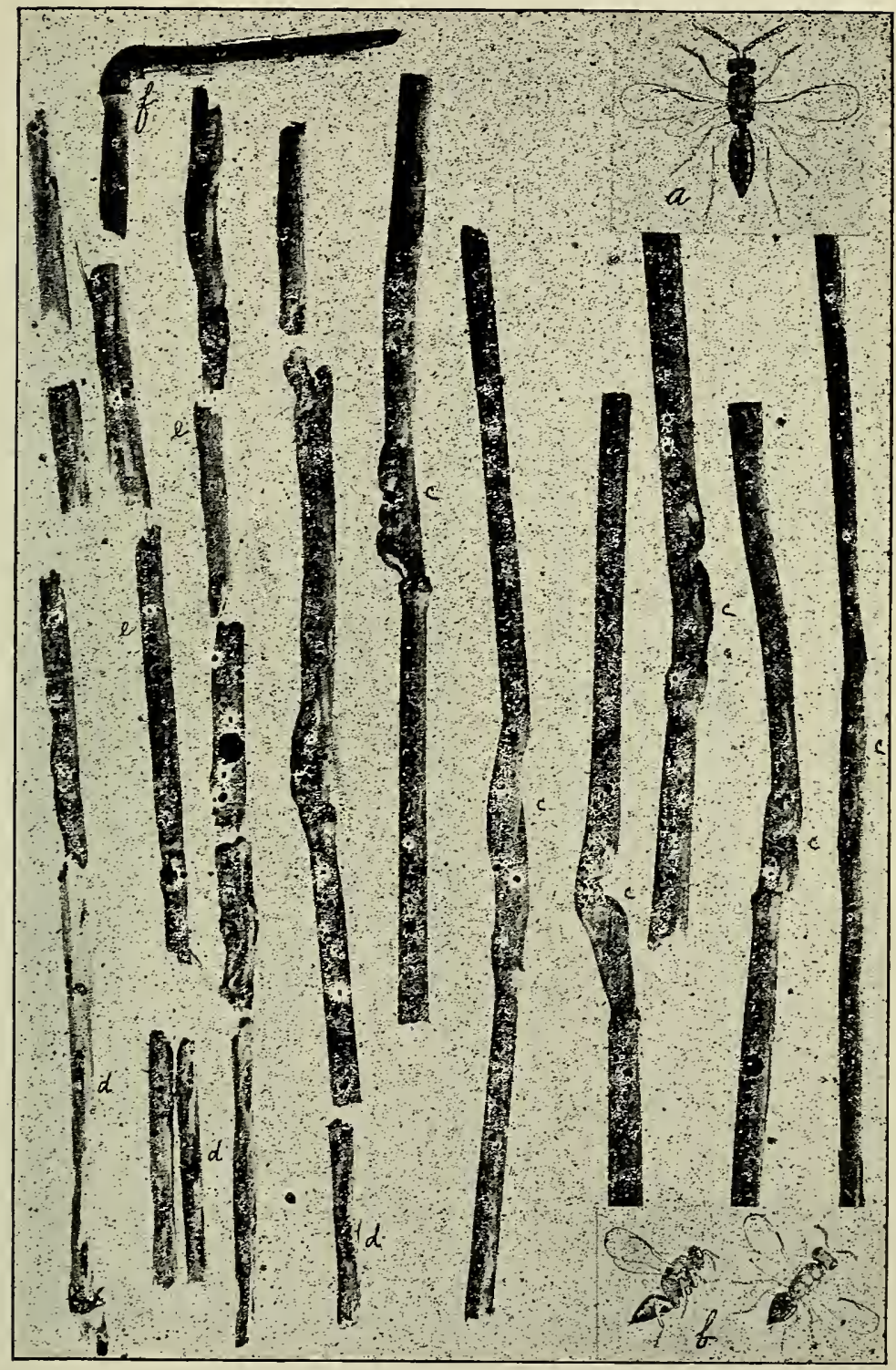

WORK OF THE JOINT WORM IN WHEAT. 



\section{NOTICE.}

Application for bulletius of this Station should be addressed to the Director of the West Virginia Agricultural Experiment Station, Morgantown, W. Va.

(The bulletins named below are available for distribution.) No. 4. The Creamery Industry; Its Adaptability to West Virginia.

No. 5. The Selection of Milch Cows.

No. 6. Six Month's Experience in Running a Creamery, Improved Process of Handling Cream and Churning.

No. 12. The Canada Thistle.

No. 14. Farm and Garden Insects and Experiments with Remedies; Note of the Season.

No. 15. Raspberry Gouty-Gall Beetle.

No. 16. Yellow Locust, Insect Ravages upon.

No. 17. Black Spruce, Insect Ravages.

No. 19. Your Weeds and Your Neighbor's Part 1. Weeds as Fertilizers.

No. 20. Potato Culture and Fertilization. Tests of Some Varieties of Tomatoes.

No. 21. Injurious Insects and Plant Diseases.

No. 25. Plat Experiments with Commercial Fertilizers on Wheat.

No. 26. Inspection of Commercial Fertilizers.

No. 27. Notes on Pruning.

No. 28. Plat Experiments with Commercial Fertilizers on Corn.

No. 29. Experiments with ¿Potatoes at the Station. Experiments on Corn at the Out-Stations.

No. 30. Address and Notes on Sheep.

No. 33. Sub Irrigation in the Green House.

No. 38. Potato Blight, Potato Scab.

No. 40. Commercial Fertilizers.

No. 42. Vegetables.

No. 43. When, Why, What and How to Spray 
No. 44. Practical Entomology.

Special Bulletin No. 2. Proceedings connected with the celebration upon the completion of the Station Building and the organization of the Sheep breeders and Wool-Growers' Association and the State Horticultural Society.

Third Anunal Report, 1890.

No. 51. Commercial Fertilizers, Jan. '98.

No. 52. Strawberries.

No. 53. Commercial Fertilizers, Dec. '98.

No. 54. Nursery Hints.

No. 55. Sugar Beets.

No. 56. Report on Investigations to Determine the Cause of Unhealthy Conditions of the Spruce and Pine From 1880-1893.

No. 57. Commercial Fertillizers.

No. 58. The Effect of Pressure in the Preservation of Milk

No. 59. Whole Corn Compared with Corn Meal for Fattening Hogs.

No. 60. Poultry Experiments.

No. 61. Sheep Feeding Experiments.

No. 62. A Study of the Effects of Incandescent Gas-light on Plant Growth.

No. 63. Commercial Fertilizers, 1899.

No. 64. Sugar Beet Investigation in 1899.

No. 65. Commercial Fertilizers.

No. 66. Fruit Diseases and How to Treat Them.

No. 67. 'The Hessian Fly in West Virginia.

No. 68. The Periodical Cicada or Seventeen Year Locust in West Virginia. A Revision of Bulletin No. 50. 

$c^{-10}=7$

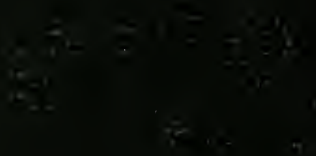

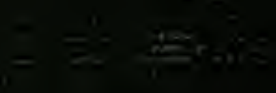

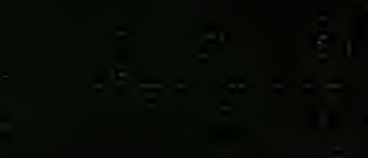

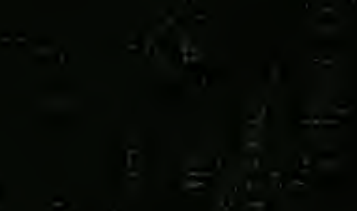

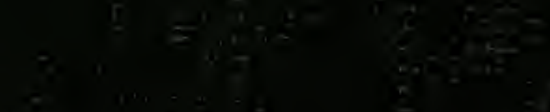

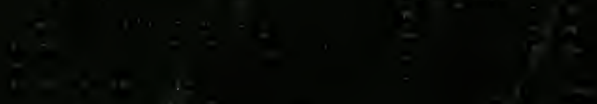

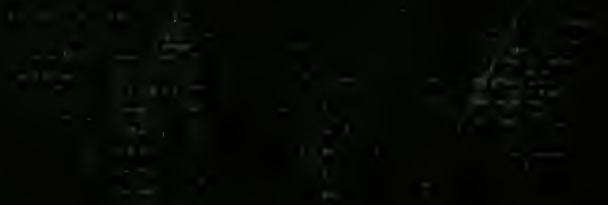

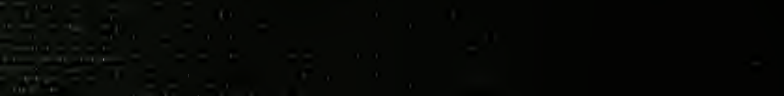

